\title{
Effect of Imbrasia belina (Westwood) or Vigna subterranea (L) Verde or Tylosema esculentum (Burchell) Schreiber as protein sources in diets fed to Tswana hens on egg quality
}

\author{
Manyeula F. ${ }^{\star}$, Tsopito C. M. ${ }^{1}$, Kamau J. M. ${ }^{1}$, Mogotsi K. K. ${ }^{1}$, Nsoso S. J. ${ }^{1}$ and Moreki J. C.. ${ }^{2}$ \\ ${ }^{1}$ Department of Animal Science and Production, Botswana University of Agriculture and Natural Resources, Private Bag \\ 0027, Gaborone, Botswana. \\ ${ }^{2}$ Department of Corporate Services, Ministry of Agricultural Development and Food Security, Private Bag 003 , \\ Gaborone, Botswana. \\ Corresponding author. Email: manyeulafreddy@yahoo.com
}

Copyright (C) 2018 Manyeula et al. This article remains permanently open access under the terms of the Creative Commons Attribution License 4.0, which permits unrestricted use, distribution, and reproduction in any medium, provided the original work is properly cited.

Received 22nd November, 2018; Accepted 12th December, 2018

\begin{abstract}
A 90 days study was conducted to compare the effects of feeding Tswana hens reared under intensive system and fed diets formulated from Imbrasia belina (Westwood), Vigna subterranea (L) Verde and Tylosema esculentum (Burchell) Schreiber as sources of protein on egg quality. Four isonitrogenous and isocaloric diets were formulated by totally replacing soybean meal (SBM) with I. belina, V. subterranea and $T$. esculentum as protein sources while commercial layer diet was used as control diet. Twelve eggs from each pen were collected at 28, 33 and 38 weeks of age for egg quality analysis in a completely randomized design. Egg weight (EW), shell weight (SW), shell thickness (ST), shell index $(\mathrm{SI})$, shell percentage (SP), egg surface area (ESA), egg volume (EV), egg contents (EC) and Haugh units (HU) were measured. Repeated measure analysis showed significant $(P<0.05)$ week $\times$ diets interaction effect on EW and SW. At week 28, hens on $T$. esculentum diet had the highest $(P<0.05) \mathrm{EW}$ while those on control diet attained the highest $(P<$ $0.05) \mathrm{EW}$ at week 33. Hens fed I. belina diets had the highest $(P<0.05) \mathrm{SW}$ at week 28. However, at weeks 33 and 38 , hens on $I$. belina diets had the smallest $(P<0.05) S W$. Hens fed $V$. subterranea and $T$. esculentum diets had significantly lower overall SI compared to those on control and I. belina diets. Tylosema esculentum diets did not promote $(P<0.05)$ ESA, EV and EC. However, no influence $(P>0.05)$ of dietary treatments was observed on overall ST, SP and HU. The inclusion of $I$. belina and $V$. subterranea on layer diet had no adverse effects on egg quality while the totally replacement of SBM with $T$. esculentum as protein source impaired egg quality. These results, suggest that $I$. belina and $V$. subterranea could completely replace SBM as protein source in the layer diets without any detrimental effects on egg quality.
\end{abstract}

Keywords: Anti-nutritional factors, egg quality, legumes, protein, Tswana chicken.

\section{INTRODUCTION}

Morama bean (Tylosema esculentum (Burchell) Schreiber) seeds, Bambara groundnuts (Vigna subterranea (L) Verde) seeds and Phane (Imbrasia belina (Westwood)) can be important soybean meal (SBM) substitutes in poultry diets in Botswana. The use of $l$. belina (Westwood) and legumes (Abdelnour et al., 2018) as source of protein for the poultry feed industry is expected to increase further in the near future. This is as a result of Bovine Spongiform Encephalopathy (BSE) outbreak in the United Kingdom in 1986, which was thought to be spread by the inclusion of animal by-products in animal feeds. The incident resulted in many livestock 
feed industries either choosing to or being banned from using animal by-products as sources of protein (Farrell, 1997). In Botswana, protein sources (i.e., feather meal, blood meal and meat-on-bones) generated by the poultry industry are by law not allowed to be included in poultry diets. As a result, plants are the major sources of protein available for poultry feeding. Although some of these plant proteins contain sufficient amount of protein $(\sim 40 \%)$ as well as, an essential amino acid profile closely matching that of SBM (Anjos, 2014), the presence of several antinutritional factors (ANFs), which include glucosinolates, sinapine, phytic acid, polyphenolic compounds, erucic acid, protein inhibitors and the indigestible non-starch polysaccharides, may negatively influence egg quality in poultry production (Wickramasuriya et al., 2015).

Legumes are low in sulphur amino acids. Therefore, to improve nutritive value and to reduce adverse effects of legume seeds, most researches have centered on supplementation of methionine. A number of feeding trials with some legumes have been carried out with poultry species. For example, Ciurescu and Pană (2017) studied the effects of untreated field pea (Pisum sativum L.) as substitute for SBM and enzymes supplementation on egg production and quality of laying hens. The authors concluded that field pea could be included in laying hen diets at dietary level up to $350 \mathrm{~g} / \mathrm{kg}$. However, other studies showed that addition of alternative legume seeds such as peas and faba beans in the layer diet significantly affected yolk colour (Laudadio and Tufarelli, 2012).

There is little information on the egg quality responses of Tswana hens to the use of $T$. esculentum seeds, $V$. subterranea seeds and $I$. belina as dietary protein sources. This study was conducted to investigate the effect of totally replacing SBM with graded levels of $T$. esculentum seeds, $V$. subterranea seeds and I. belina in diets for Tswana hens on egg quality traits. It was hypothesised that replacing SBM with $T$. esculentum, $V$. subterranea and $I$. belina in layer diets would have no adverse effects on egg quality characteristics.

\section{MATERIAL AND METHODS}

\section{Study area}

The experiment was carried out from February to May 2010 at Botswana College of Agriculture (now Botswana University of Agriculture and Natural Resource), Content Farm in Sebele. The farm is located $10 \mathrm{~km}$ north of Gaborone, the capital city of Botswana. During the study period the temperature ranged between 19 and $25^{\circ} \mathrm{C}$.

\section{Birds and their management}

A total of 60 normal feathered Tswana hens aged 25 weeks (point of lay) were used in the study. The hens were raised under semi-intensive system supplemented with maize before the start of the study. At the beginning of the study, birds were individually weighed and tagged. All the hens were vaccinated against Newcastle disease and infectious bursal disease (IBD) and were raised on a deep litter system. Clean water was provided ad libitum for 90 days and the house lit continuously for 16 hours.

\section{Chemical analysis of the feedstuff}

Prior to diet formulation, proximate analysis of $I$. belina (Westwood), V. subterranean (L) Verde and T. esculentum (Burchell) Schreiber were determined by the method of AOAC (2005). Calcium (Ca) was analyzed using Inductively Coupled Plasma Mass Optical Emission Spectrometer (Optical 2100DV model) while phosphorus (P) was determined using Kjeldahl digestion by ultraviolet spectrophotometer (Shimadzu UV 160 pc model) (AOAC, 2005). Table 1 presents the chemical composition of the protein sources used in the diet formulations (\%DM). I. belina, $T$. esculentum and $V$. subterranea were ground and mixed with other ingredients to formulate $I$. belina diet, $T$. esculentum diet and $V$. subterranea diet respectively in a mash form. Diets were isonitrogenous (16\% CP) and isocaloric $(13 \mathrm{MJ} / \mathrm{Kg})$ and were formulated to meet the nutritional value of the control diet (commercial layer diet) as recommended by National Research Council (1996). The $T$. esculentum and $V$. subterranea diets were supplemented with $\mathrm{DL}$ methionine and lysine to ensure that these amino acids were not limiting for egg production and quality. The feed mixer auger (pet 14, animal shredder hammer mill foliage TRF 600) was used to mix different diets homogeneously. Ingredients used in the formulation of the different diets are shown in Table 2.

\section{Diet formulation}

Four experimental diets containing either roasted I. belina or dehulled $T$. esculentum or $V$. subterranea and soybean meal as sources of protein were formulated using the Feed Mixer Computer Software (OSUNRC 2002 model). Roasted I. belina was purchased from local farmers in Tsetsebye in the Central District while dehulled $T$. esculentum (Burchell) Schreiber was obtained from Letlhakeng in Kweneng District and dehulled $V$. subterranea (L) Verde from the Botswana Agricultural Marketing Board in Gaborone.

\section{Experimental design}

Four experimental diets consisting of $V$. subterranea (L) Verde, T. esculentum (Burchell) Schreiber, I. belina (Westwood), and commercial layer diet (mash) were used 
Table 1. Chemical composition of Zea mays, T. esculentum, V. subterranea and I. belina used in the present study.

\begin{tabular}{lcccc}
\hline \multirow{2}{*}{ Parameters } & \multicolumn{4}{c}{ Ingredients } \\
\cline { 2 - 5 } & Z. mays & T. esculentum & V. subterranea & I. belina \\
\hline Dry matter (\%) & $79.3 \pm 1.4$ & $90.1 \pm 4.2$ & $89.3 \pm 5.7$ & $91.4 \pm 8.5$ \\
CP (\%) & $7.0 \pm 0.1$ & $30.0 \pm 1.6$ & $18 \pm 0.7$ & $54 \pm 3.7$ \\
Crude fibre (\%) & $1.0 \pm 0.1$ & $17.0 \pm 3.2$ & $4.1 \pm 0.0$ & $8.1 \pm 0.0$ \\
Crude fats (\%) & $4.1 \pm 0.1$ & $40.0 \pm 2.3$ & $5.9 \pm 0.5$ & $13.9 \pm 2.1$ \\
Ash (\%) & $0.7 \pm 0.1$ & $1.2 \pm 0.2$ & $1.1 \pm 0.2$ & $5.4 \pm 0.1$ \\
Calcium (\%) & $0.6 \pm 0.0$ & $0.6 \pm 0.0$ & $0.40 \pm 0.1$ & $0.7 \pm 0.0$ \\
Phosphorus (\%) & $0.3 \pm 0.0$ & $0.5 \pm 0.0$ & $0.5 \pm 0.0$ & $0.5 \pm 0.0$ \\
Gross energy (MJ/kg) & $1.638 \pm 0.0$ & $1.993 \pm 0.0$ & $2.440 \pm 0.0$ & $1.713 \pm 0.0$ \\
\hline
\end{tabular}

Table 2. Ingredients and nutrient composition of experimental diets formulated from $T$. esculentum, $V$. subterranea, $I$. belina and commercial diets.

\begin{tabular}{|c|c|c|c|c|}
\hline Ingredients & T. esculentum & V. subterranea & I. belina & Commercial \\
\hline Yellow maize (\%) & 59.0 & 19.0 & 78.0 & * \\
\hline T. esculentum (\%) & 37.0 & 0 & 0 & * \\
\hline V. subterranea (\%) & 0 & 77.0 & 0 & * \\
\hline I. belina (\%) & 0.0 & 0 & 18.0 & * \\
\hline Dicalcium phosphate & 1.2 & 1.1 & 1.2 & * \\
\hline Limestone (\%) & 1.1 & 1.2 & 1.1 & * \\
\hline lodized (\%) & 0.4 & 0.4 & 0.4 & * \\
\hline Vat Mineral premix & 0.1 & 0.1 & 0.1 & * \\
\hline DL-methionine (98\%) & 0.6 & 0.6 & 0.6 & * \\
\hline Lysine HCL (\%) & 0.6 & 0.6 & 0.6 & 0.6 \\
\hline \multicolumn{5}{|l|}{ Calculated analysis } \\
\hline Met. Energy (MJ/Kg) & 13.7 & 13.4 & 13.8 & 13.0 \\
\hline Crude protein (\%) & 16.0 & 16.1 & 16.0 & 16.0 \\
\hline Calcium (\%) & 3.5 & 3.5 & 4.2 & 4.5 \\
\hline Phosphorus (\%) & 0.9 & 0.8 & 0.1 & 0.5 \\
\hline \multicolumn{5}{|l|}{ Determined analysis } \\
\hline Dry matter (\%) & $93.8 \pm 4.2$ & $93.5 \pm 43.9$ & $93.5 \pm 15.1$ & $84.0 \pm 2.5$ \\
\hline Crude protein (\%) & $16.0 \pm 2.0$ & $16.0 \pm 2.0$ & $16.0 \pm 0.8$ & $16.0 \pm 0.8$ \\
\hline
\end{tabular}

in this study. Twelve pens each measuring $1.2 \mathrm{~m}$ by $2 \mathrm{~m}$ and 60 Tswana hens were used. Five chickens were randomly allocated to each pen. The diets were then randomly allocated to the 12 pens such that each diet was replicated three times. The design of the experiment was therefore a completely randomized design (CRD) with four treatments, three replications and five sampling units per replication. The number of replications was determined using a resource equation (Mead, 2000) to ensure minimum degrees of freedom of error. The resource equation is given as:

$\mathrm{E}=\mathrm{N}-\mathrm{T}$

Where $E$ is the error degrees of freedom and should be between 10 and $20, \mathrm{~N}$ is the total degree of freedom and $\mathrm{T}$ is the treatment degrees of freedom. 


\section{Measurement of parameters}

Thirty-six eggs (12 from each replicate) from each treatment were collected at 28, 33 and 38 weeks of age for egg quality analysis. The eggs were weighed using an electronic scale sensitive to $0.001 \mathrm{~g}$. The height, width of eggs and shell thickness were measured using Micrometer screw gauge sensitive to $0.001 \mathrm{~mm}$. Thereafter, the eggs were cracked open on a white tile and shell thickness was measured according to Alkan et al. (2008). The shells were washed under slow flowing water to remove adhering albumen (Kuhl and Seker, 2004) and then wiped with a paper towel to remove excessive moisture. Egg shell thickness (ST) was estimated in the three locations (sharp, blunt and equator). Egg shape index (\%) was calculated as [egg width $(\mathrm{cm}) /$ egg length $\left.(\mathrm{cm})^{\star} 100\right]$. Egg surface area (ESA) was expressed in centimeter squared $\left(\mathrm{cm}^{2}\right)$ using formula of Carter (1975), 3.9782W ${ }^{0.7056}$, where W is the egg weight (EW) in grams. Egg content (EC) was calculated by subtracting shell weight (SW) from EW while egg volume (EV) was measured using the formula of Carter (1975). Shell percentage (SP) was expressed as SW divided by ESA multiplied by 100 whereas Haugh unit $(\mathrm{HU})$ was calculated using the formula 100log $(\mathrm{H}+7.57-$ $1.7 \mathrm{~W}^{0.37}$ ), where $\mathrm{H}$ is the albumen height and $\mathrm{W}$ is the $\mathrm{EW}$ (Haugh, 1937). For clarity purpose, the formulae are given below:

Shape index $(\%)=\frac{\text { Egg width }(\mathrm{cm})}{\text { Egg length }(\mathrm{cm})} \times 100$

Egg Surface Area $\left(\mathrm{mm}^{2}\right)=3.9782 \mathrm{~W}^{0.7056}$

Where $\mathrm{W}=$ egg weight $(\mathrm{g})$

Egg Content $(\mathrm{g})=$ Egg weight $(\mathrm{g})-$ Shell weight (g)

Shell Percentage $(\%)=\frac{\text { Egg weight }(\mathrm{g})}{\text { Egg surface area }\left(\mathrm{mm}^{2}\right)} \times 100$

Haugh unit $=100 \log \left(\mathrm{H}+7.57-1.7 \mathrm{~W}^{0.37}\right)$

Where: $\mathrm{H}=$ albumen height and $\mathrm{W}=$ egg weight.

\section{Statistical Analysis}

Data on egg quality were analysed using repeated measures procedure of SAS (2010) according to the following general linear model:

$$
Y_{i j k}=\mu+D_{i}+W_{j}+\left(D \times W_{i j}\right)+E_{i j k}
$$

where $Y_{i j k}=$ response variable, $\mu=$ overall mean, $D_{i}=$ fixed effects of diet, $W_{j}=$ effects of week (age of chicken), ( $\mathrm{x}$ $W)_{i j}=$ effects of interaction between diets and week and
$E_{\mathrm{ijk}}=$ experimental error (variation within the pens), ijk = sampling error (variation within the hens).

The probability of difference (PDIFF) option in the LSMEANS statement of the GLM procedure of SAS (2010) was used to separate means. Statistical significance was declared at $\mathrm{P} \leq 0.05$.

\section{RESULTS}

Repeated measure analysis showed significant $(P<0.05)$ week $\times$ diets interaction effect on EW and SW (Table 3). At week 28, hens on $T$. esculentum diet had the highest $(\mathrm{P}<0.05) \mathrm{EW}$ while control, V. subterranea and I. belina diets had the lowest. Also, at week 33, hens on control diet had the highest $(P<0.05)$ EW while the lowest EW was found in hens on $V$. subterranea, $T$. esculentum and $I$. belina diets. However, no differences in EW were detected at week 38 in all diets. Hens on $T$. esculentum diet had the lowest $(P<0.05) E W$ in all diets and weeks, whereas hens on $I$. belina diets had the highest $(P<0.05) \mathrm{EW}$ at week 33 and 38. At weeks 33 and 38, hens on I. belina diets also had the smallest $(P<0.05)$ SW. Repeated measure analysis showed no significant $(P>0.05)$ diet $\times$ week interaction effect on ST, SI, SP, ESA, EV, EC and HU (Table 4) while experimental diets had effects on overall ST, SI, SP, ESA, EV, EC and HU. Hens fed V. subterranea and $T$. esculentum diets had significantly lower overall $\mathrm{SI}$ than those on control and I. belina diets. However, hens on control, $V$. subterranea and $I$. belina diets had similar $(\mathrm{P}$ $>0.05$ ) overall ESA, EV and EC while those on $T$. esculentum diets had the lowest ESA, EV and EC. No influence $(P>0.05)$ of dietary treatment on overall ST, SP and $\mathrm{HU}$ was observed.

\section{DISCUSSION}

One of the most important consideration in diet formulation is the availability and nutritional value of amino acids (Kim et al., 2011), which depend to a large extent on the nutrient composition and concentration of ANFs in the feedstuff. Previous study by Manyeula et al. (2013) reported that replacement of SBM with I. belina, $V$. subterranea and $T$. esculentum may ensure adequate digestible amino acids. In this study, replacement of SBM with $T$. esculentum was seen to reduce EW, which could be a result of low feed intake reported by Manyeula et al. (2013) and the presence of ANFs. Ferket and Gernat (2006) stated that feed intake is the single-most important factor that will determine the efficiency of nutrient utilization. As chickens decrease feed intake, their nutrient intake also decreases resulting in lighter weight. Anti-nutritional factors found in $T$. esculentum are known to suppress nutrient digestibility in chickens (Madzimure et al., 2017). In addition, Jackson et al. (2010) 
Table 3. Eggs and shell weight of Tswana hens raised under intensive systems and fed diets containing $I$. belina, $T$. esculentum, $V$. subterranea and a commercial layer diet at different ages in weeks.

\begin{tabular}{|c|c|c|c|c|c|}
\hline Parameter & Age & Control & V. subterranea & T. esculentum & I. belina \\
\hline \multirow{3}{*}{ Egg weight (g) } & 28 & $53.3 \pm 0.7^{\text {ay }}$ & $53.9 \pm 0.7^{\text {ay }}$ & $48.8 \pm 0.7^{b x}$ & $51.8 \pm 0.7^{\text {ay }}$ \\
\hline & 33 & $54.2 \pm 0.7^{\text {ay }}$ & $53.9 \pm 0.7^{\mathrm{ax}}$ & $49.6 \pm 0.7^{b x}$ & $53.6 \pm 0.7^{\mathrm{ax}}$ \\
\hline & 38 & $55.4 \pm 0.7^{\mathrm{ax}}$ & $53.7 \pm 0.7^{\mathrm{bx}}$ & $50.2 \pm 0.7^{b x}$ & $55.2 \pm 0.7^{\mathrm{ax}}$ \\
\hline \multirow{3}{*}{ Shell weight $(\mathrm{g})$} & 28 & $6.4 \pm 0.4^{b x}$ & $6.0 \pm 0.4^{b x}$ & $6.8 \pm 0.4^{b x}$ & $7.8 \pm 0.4^{\mathrm{ax}}$ \\
\hline & 33 & $6.9 \pm 0.4^{a x}$ & $6.0 \pm 0.4^{\mathrm{ax}}$ & $6.7 \pm 0.4^{\mathrm{ax}}$ & $5.9 \pm 0.4^{\text {by }}$ \\
\hline & 38 & $6.6 \pm 0.4^{a x}$ & $6.3 \pm 0.4^{\mathrm{ax}}$ & $6.9 \pm 0.4^{\mathrm{ax}}$ & $5.7 \pm 0.4^{\text {by }}$ \\
\hline
\end{tabular}

${ }^{a b c}$ Means in the same row with a common superscript do not differ $(P>0.05) .{ }^{x y z}$ Means in the same column with a common superscript do not differ $(P>0.05)$. EW = egg weight, $S W=$ shell weight.

Table 4. Effects of diets containing I. belina, T. esculentum and V. subterranea and control diet on egg quality of Tswana hens.

\begin{tabular}{lccccc}
\hline Egg quality parameters & Control & V. subterranea & T. esculentum & I. belina & SE \\
\hline Shell thickness $(\mathrm{mm})$ & 0.6 & 0.5 & 0.4 & 0.6 & 0.2 \\
Shell index $(\%)$ & $76.9^{\mathrm{a}}$ & $73.7^{\mathrm{c}}$ & $72.6^{\mathrm{c}}$ & $76.1^{\mathrm{b}}$ & 0.8 \\
Shell Percentage (\%) & 12.3 & 11.3 & 13.4 & 11.4 & 0.8 \\
Egg shell area $\left(\mathrm{mm}^{2}\right)$ & $66.6^{\mathrm{a}}$ & $66.2^{\mathrm{a}}$ & $62.4^{\mathrm{b}}$ & $66.0^{\mathrm{a}}$ & 0.6 \\
Egg volume $\left(\mathrm{mm}^{3}\right)$ & $43.3^{\mathrm{a}}$ & $42.8^{\mathrm{a}}$ & $39.6^{\mathrm{b}}$ & $42.4^{\mathrm{a}}$ & 0.6 \\
Egg content $(\mathrm{g})$ & $47.7^{\mathrm{a}}$ & $47.6^{\mathrm{a}}$ & $42.7^{\mathrm{b}}$ & $46.7^{\mathrm{a}}$ & 0.8 \\
Haugh unit & 99.8 & 99.1 & 99.5 & 100.1 & 1.8 \\
\hline
\end{tabular}

abcMeans in the same row with a common superscript do not differ $(P>0.05)$.

reported T. esculentum (Burchell) to be a potential source of phytonutrients including phenolic compounds such as tannin, trypsin inhibitor, phytate and oligosaccharides. In a related study, Tshovhote et al. (2003) found that tannin decreases the digestibility of protein and carbohydrates by forming insoluble enzyme resistant complexes with the dietary protein. On the other hand, trypsin inhibitor binds protein on the ileal epithelium. The presence of tannins, trypsin inhibitor and phytates in $T$. esculentum diet in this study could have reduced the metabolism of the dietary protein and subsequently had adverse effect on egg formation and bone integrity. Phytate has a tendency to bind calcium and phosphorus thereby making them unavailable in sufficient quantities for egg formation. The presence of phytate on the feed results in low EW. The reduction in EW is consistent with earlier work of Alkanji and Ologhobo (2007) who found that elevated phytate contents in raw seed legumes contribute to the reduction in EW.

The tendency of EW to increase with age in the present study agrees with Aziza et al. (2013) and Hurnik et al. (1997) who reported that egg size increases with age in layers but stabilizes within 4 to 6 weeks of laying.

Leeson and Summers (1997) and Munisi et al. (2016) observed that EW is lowest at the beginning of the production cycle but increases as age and body weight increases throughout the laying period. In the present study, EW of Tswana hens was not influenced by replacement of $I$. belina, $V$. subterranea and $T$. esculentum with SBM. This suggests that inclusion of these protein sources did not alter the physico-chemical parameters of the diet and thus did not affect its palatability and functional properties. This result is consistent with Akhatar et al. (2007) who reported mean value of $6.26 \pm 0.478 \mathrm{~g}$ for Fayoumi hens of Pakistan but higher than SW reported by Tuleun et al. (2008) in laying hens fed velvet beans. The tendency of SW to increase with age in this study is in agreement with Moreki et al. (2011) who reported an increase in SW of Ross broiler breeder hens from 27 to 30 weeks of age.

Repeated measure analysis showed no diet $\times$ week interaction effect on ST, SI, SP, ESA, EV, EC and HU demonstrating that the effects of diet in these parameters did not depend on the age of hens. The replacement of SBM with $I$. belina, $V$. subterranea and $T$. esculentum did not improve egg quality as indicated by lack of difference between eggs from hens fed control diet and other dietary treatment in terms of ST, SP and HU. The present results on ST falls within the mean value of $0.38 \pm 0.005 \mathrm{~mm}$ reported by Minh et al. (2004) in the scavenging chicken supplemented with protein. Similar results were reported by Tulenu et al. (2008) when layers were fed velvet bean. 
However, Minh et al. (2004) reported a lower SP $(9.3 \pm 0.15$ to $10.4 \pm 0.15 \%$ ) in scavenging hens supplemented with protein in Northern Vietnam. Diets and age also had no significant influence on HU. This result is in line with Gul et al. (2005) who reported HU above $72(84.7 \pm 1.3$ to $90.2 \pm 1.3$ ) in eggs from hens fed a high level of common vetch seed (legumes) during peak period.

Eggs from hens on $T$. esculentum diet had low overall $\mathrm{ESA}, \mathrm{EV}$ and $\mathrm{EC}$; this is not surprising as there is a strong relationship between EW and the latter parameters. As shown in Table 3, EW was suppressed by feeding $T$. esculentum diet, indicating that ESA, EV and EC are positively correlated to EW. The formula of Carter (1975) indicates that the determination of ESA, EV and EC is dependent on EW. It is therefore, logical that a decrease in EW due to highlighted factors would result in a concomitant decrease in these parameters. In this study, the reduced EC is not surprising as there is a strong relationship between dietary protein and EC. Gunawardana et al. (2008) reported that EC (egg weight, mass, albumen and yolk weight) decreases with decreased dietary protein, which explains why eggs had a decreased EC. The tendency of ESA, EV and EC to increase with age of the hens could be due to the increase in EW and body size.

\section{Conclusions}

These results suggest that inclusion of $l$. belina (Westwood) and $V$. subterranea (L) Verde as sources of protein in layer diets had no adverse effects on egg quality. However, T. esculentum (Burchell) resulted in poor egg quality suggesting the need to take precautionary measures when using $T$. esculentum in place of SBM. These measures may include exogenous enzyme treatment to increase utilization and breakdown of mineralphytic acid complexes.

\section{Recommendation}

It is recommended that $I$. belina (Westwood) and $V$. subterranea $(L)$ Verde processed seeds can be used as alternative protein sources in layer diets for Tswana chicken hens.

\section{CONFLICT OF INTEREST}

The authors declare that they have no competing interests

\section{ACKNOWLEDGEMENT}

The authors wish to acknowledge with gratitude the financial support provided by Useful Plants Project while Dr. B. Sebolai and Mr. J. Makore are thanked for assistance with statistical analysis.

\section{REFERENCES}

Abdelnour, S. A., Mohamed, E., El-Hack, A., \& Ragni, M. (2018). The efficacy of high-protein tropical forages as alternative protein sources for chickens: A Review. Agriculture, 8, 1-14.

Akhatar, S., Hassan, M., \& Yasmeen, F. (2007). Comparative study of production potential and egg characteristics of Lyallpur silver black, Fayoumi and Rhode Island. Pakistan Veterinary Journal, 27, 187-188.

Alkan, S., Karabag, K., Galic, A., \& Balcioglu, M. S. (2008). Effects of genotype and egg weight on hatchability traits and hatching weight in Japanese quail. South African Journal of Animal Science, 38, 231-237.

Alkanji, A. M., \& Ologhobo, A. D. (2007). Effects of some raw tropical legumes seeds on egg quality and laying performance of exotic hens. American-Eurasian Journal Agriculture and Environmental Science, 2, 648-654.

Anjos, F. R. D. (2014). Improving the nutritive value and utilization of non-convectional protein feed resources in smallholder village chicken production. Ph.D Thesis, University of Kwazulu-Natal, Pietermaritzburg, South Africa.

AOAC (2005). Official Methods of Analysis of AOAC International, $18^{\text {th }}$ ed. Association of Official Analytical Chemists, Arlington, VA, USA.

Aziza, E., Panda, A. K., Quezada, N., \& Cherian, G. (2013). Nutrient digestibility, egg quality, and fatty acid composition of brown laying hens fed camelina or flaxseed meal. Journal Applied Poultry Research, 22, 832-841.

Carter, T. C. (1975). The hen's egg: Estimation of superficial area and egg volume, using measurement of fresh egg weight and shell length and breadth alone or in combination. British Poultry Science, 16, 541-543.

Ciurescu, G., \& Pană, C. O. (2017). Effect of dietary untreated field pea (Pisum sativum L.) as substitute for soybean meal and enzymes supplementation on egg production and quality of laying hens. Romanian Biotechnological Letters, 22(1), 12204-12213.

Farrell, D. J. (1997). Where in the world will we find the ingredients to feed our livestock by the year 2007? Recent Advances in Animal Nutrition, U.N.E., Armidale, Australia. Pp. 136-145.

Ferket, P. R., \& Gernat, A. G. (2006). Factors that affect feed intake of meat type birds. International. Journal Poultry Science, 5, 905-911.

Gul, M., Yoruk, M. A., Hayirli, A., Turgut, L., \& Karaoglu, M. (2005). Effects of additives on laying performance and egg quality of hens fed a high level of common vetch seed (Vicia sativa) during the peak. Journal of Applied Poultry Research, 14, 217-225.

Gunawardana, P., Roland Sr., D. A., \& Bryant, M. M. (2008). Effect of energy and protein on performance, egg components, egg solids, egg quality, and profits in molted Hy-Line W-36 hens. Journal of Applied Poultry Research, 17, 432-439.

Haugh, R. R. (1937). The Haugh unit for measuring egg quality. USA Egg Poultry Magazine, 43, 552-55.

Hurnik, J. F., Summers, J. D., Reinhard. D. S., \& Sweirczewks, A. (1997). Effects of age in the performance of laying hens during the first year of production. Journal of Poultry Science, 56, 222-230.

Jackson, J. C., Duodu, K. G, Holse, M., de Faria, M. D., Jordan, D., Chingwaru, W., Hansen, A., Kandawa-Schultz, M., Mpotokwane, S. M., Chimwamurombe, P., de Kock, H. L., \& 
Minnaar, A. (2010). The Morama bean (Tylosema esculentum): A potential crop for Southern Africa. Advanced Food Nutrition Resources, 61, 187-246.

Kim, J., Kundu, M., Viollet, B., \& Guan, K.L. (2011). AMPK and mTOR regulate autophagy through direct phosphorylation of Ulk1. Natural Cell Biology, 13, 132-14.

Kuhl, S., \& Seker, I. (2004). Phenotypic correlations between some external and internal egg quality traits in the Japanese quail. International Journal Poultry Science, 3, 400-405.

Laudadio, V., \& Tufarelli, V. (2012). Effect of treated field pea (Pisum sativum L. CV Spirale) as substitute for soybean extracted meal in a wheat middlings-based diet on egg production and quality of early laying brown hens. Arch Geflügelk, 76, 1-5.

Leeson, M., \& Summers, J. D. (1997). Commercial Poultry Nutrition $2^{\text {nd }}$ edition, Guelph.

Madzimure, J., Muchapa, L., Gwiriri, L., Bakare, A. G., \& Masaka, L. (2017). Growth performance of broilers fed on sproutedroasted guar bean (Cyamopsis tetragonoloba) based diets. Tropical Animal Health and Production, 49, 1009-1013.

Manyeula, F., Tsopito, C. M., Kamau, J., Mogotsi, K. K., Nsoso, N. J., \& Moreki, J. C. (2013). The effects of Imbresia belina, (Westwood), Tylosema esculentum, (Burchell) Schreiber and Vigna subterranean $(\mathrm{L})$ Verde as protein source on growth and laying performance of Tswana hens raised under intensive production system. Scientific Journal of Animal Science, 2(1), 1-8.

Mead, R. (2000). The design of experimental. Cambridge, New York, Cambridge University Press, PP.620.

Minh, D. V., Lindberg, E. J., \& Ogle, B. (2004). Effects of scavenging and protein supplementation on the feed intake and performance of improved pullets and laying hens in Northern Vietnam. Asian-Australian Journal of Animal Science, 17, 1553-1561.
Moreki, J. C., Van der Merwe, H. J., \& Hayes, J. P. (2011). Effects of calcium level on egg production and shell quality in broiler breeder hens at peak production. Research Opinions in Animal and Veterinary Science, 1, 19-26.

Munisi, W. G., Katule, A. M., \& Mbaga, S. H. (2016). Comparisons of egg production and quality traits of parental and crosses of broiler and Black Australorp chickens in Tanzania. Livestock Research for Rural Development. Volume 28, Article \#111.

National Research Council, (1996). Nutrient requirement of poultry. $9^{\text {th }}$ ed National Academy press. Washington. D. C.

SAS (2010). SAS Users Guide: Statistics, Version 9.3 SAS Institute, Cary, NC, USA

Tshovhote, N. J, Nesamvuni, A. E, Raphulu, T., \& Gous, R. M. (2003). The chemical composition, energy and amino acid digestibility of cowpeas used in poultry nutrition. South African Journal of Animal Science, 33, 65-69.

Tuleun, C. D., Carew, S. N., \& Ajiji, I. (2008). Feeding value of velvet beans (Mucuna utilis) for laying hens. Livestock Research for Rural Development, 20(5). Retrieved August 20, 2018, from http://www.Irrd.org//rrd20/5/tule20081.htm

Wickramasuriya, S. S., Yi, Y. J., Kim, C., Yoo, J. N., Kang, K., \& Heo, J. M. (2015). A review of canola meal as an alternative feed ingredient for ducks. Journal of Animal Science Technology, 57, 1-9. 